\title{
AC 2010-1136: THE CHALLENGE OF IMPLEMENTING THE CIVIL ENGINEERING BOK2 AT [UNIVERSITY A]
}

Kevin Hall, University of Arkansas 


\title{
The Challenge of Implementing the Civil Engineering BOK2 at [University A]
}

\begin{abstract}
The Civil Engineering Body of Knowledge for the $21^{s t}$ Century (BOK) defines the knowledge, skills, and attitudes expected of the future civil engineer. The second edition (BOK2) contains a comprehensive list of 24 outcomes which include both the content statement and a level of achievement for the outcome, based on Bloom's Taxonomy for cognitive development. This system clearly identifies the role and responsibilities of both academia and the civil engineering profession in the technical and professional development of the future engineer and his/her ultimate achievement of the BOK.
\end{abstract}

The ASCE's Body of Knowledge Educational Fulfillment Committee (BOKEdFC) examined survey data illustrating how well current curricula achieve the educational outcomes of the civil engineering BOK. This analysis identified several BOK2 outcomes as "challenging" for many programs to address in today's civil engineering curricula. The outcomes identified as challenging include Outcomes 3 - Humanities, 4 - Social Sciences, 5 - Material Science, 10 Sustainability, 11 - Contemporary Issues \& History, 12 - Risk \& Uncertainty, 17 - Public Policy, 18 - Business \& Public Administration, 19 - Globalization, 20 - Leadership, and Outcome 24 Professional \& Ethics. While there are multiple contributing factors for identifying a given outcome as challenging, in general the difficulty for most programs relates to the BOK-specified level of achievement for the outcome.

A comprehensive analysis is presented of [University A's] civil engineering curriculum with respect to the $\mathrm{BOK} 2$ outcomes at the levels of achievement associated with the baccalaureate degree. The current curriculum addresses, in some fashion, all 24 BOK2 outcomes. The program fully addresses, to the recommended level of achievement, 6 of the 24 BOK2 outcomes; the remaining 18 BOK2 outcomes are not addressed to the specified level of achievement for the baccalaureate level.

Three interrelated actions are identified as necessary for bringing the undergraduate curriculum to substantial compliance with the BOK2. The first is a review and refinement of existing program outcomes. The second involves a comprehensive curricular content review, to ensure existing courses provide both the content and the level of achievement envisioned by the BOK2. The third action relates to the refinement of existing, and development of new, assessment tools to demonstrate student achievement relative to program/BOK2 outcomes. This undertaking may require substantial effort 'up front', as well as an associated increase in efforts related to assessment data collection and analysis. Some course content may be restructured or refined; however, significant course/program restructuring - including adding, deleting, or changing courses - is not anticipated.

\section{Introduction}

The first edition of the Civil Engineering Body of Knowledge for the $21^{\text {st }}$ Century ${ }^{1}$ (BOK1) was released in January 2004. Based on various inputs, a second edition of the Civil Engineering 
Body of Knowledge for the $21^{\text {st }}$ Century $^{2}$ (BOK2) was developed from October 2005 to November 2007, and released in February 2008. The BOK1 has already impacted accreditation criteria and civil engineering curricula. The BOK2, while being more recent and not yet completely addressed within accreditation criteria, is motivating additional change in some civil engineering curricula. ${ }^{3}$ Considering specifically the BOK2, a coordinated list of 24 outcomes is presented within three outcome categories: Foundational, Technical and Professional. The outcomes define the desired level of achievement defined according to Bloom's Taxonomy for the cognitive domain ${ }^{4,5}$. Additionally, the BOK2 has recommended outcome achievement targets for each portion of the fulfillment pathway: for the baccalaureate degree (B), postbaccalaureate formal education $(\mathrm{M} / 30)$, and pre-licensure experience $(\mathrm{E})$. The emphasis herein is on those outcomes and achievement targets for the baccalaureate degree.

The BOK2 Outcomes Rubric, using Bloom's Taxonomy, is graphically presented in Figure 1. The reader is cautioned that this is simple graphical representation of the full rubric only and should refer to the full rubric as presented in Appendix I of the BOK2 report ${ }^{2}$. What is clearly represented in Figure 1 is the recommended level of achievement that an individual must demonstrate for each outcome to enter the future practice of civil engineering at the professional level and, for each outcome, the level of achievement (LOA) expected to be fulfilled through the baccalaureate degree (B), the master's degree or equivalent post-baccalaureate formal education $(\mathrm{M} / 30)$, and pre-licensure experience $(\mathrm{E})$.

Recently, ASCE's Body of Knowledge (BOK) Educational Fulfillment Committee (BOKEdFC) conducted an analysis of the degree to which civil engineering curricula, in their current design, achieve the educational outcomes of both the first and second editions of the civil engineering $\mathrm{BOK}^{6}$. The results of a curricular review by ten representative civil engineering programs were presented along with possible explanations as to why current curricula may fulfill or fall short of fulfilling specific outcomes. Figure 2 presents the results of one of the surveys, specifically one in which programs reported, for the BOK2 outcome rubric, at what level of achievement they believe all of the outcome statement is fulfilled by all of their baccalaureate graduates. A color coding was provided to assist with visualizing the results of the survey. Green cells indicate baccalaureate graduates of 8 to 10 programs are believed to be fulfilling the LOA, yellow cells indicate graduate of 5-7 programs are fulfilling the LOA, and red cells indicate baccalaureate graduates of 4 or less programs are fulfilling the specified LOA. To further help with visualizing the results, the first column of each table corresponding to the outcome number has been similarly color coded consistent with the LOA corresponding to the "B" level for each outcome. For example, Outcome 6 (Humanities) is colored red and shows that six of the ten (yellow) surveyed programs believe all of the outcome is fulfilled by all of their baccalaureate graduates at a LOA 1, five of ten (yellow) at a LOA 2, and three of ten (red) at the targeted LOA 3.

Based on the survey data and analysis, the BOKEdFC ${ }^{6}$ concluded that several BOK2 outcomes may be "challenging" for many programs to address in today's civil engineering curricula. These include the nine "red outcomes" shown in Figure 2 (i.e., Outcomes 3 - Humanities, 4 Social Sciences, 10 - Sustainability, 11 - Contemporary Issues \& History, 12 - Risk \& Uncertainty, 17 - Public Policy, 18 - Business \& Public Administration, 19 - Globalization, and 20 - Leadership). In addition, the committee identified Outcome 5 - Material Science, and 
Outcome 24 - Professional \& Ethics, as outcomes that may be challenging for programs to fully implement.

The purpose of this paper is twofold. A comprehensive analysis is presented of [University A's] civil engineering curriculum with respect to the BOK2 outcomes at the levels of achievement associated with the baccalaureate degree. Outcomes are identified as presenting the most significant challenges for achievement by the current curriculum. Subsequently, a strategy is proposed for curricula adjustments necessary to bring [University A's] program into compliance with the BOK2 - without compromising current university graduation and ABET/EAC accreditation requirements.

\section{Institutional Profile}

[University A] is a major, comprehensive, student-centered research university founded in 1871 and began offering engineering courses in 1873. Today, the university enrolls over 19,500 students. The College of Engineering, with approximately 103 tenure/tenure-track faculty in seven departments, enrolls approximately 1650 undergraduate, 578 masters, and 149 doctoral students. Last fiscal year, externally-funded research expenditures in the college exceeded $\$ 18$ million. The Department of Civil Engineering has 12 tenure/tenure-track faculty, and enrolls approximately 200 undergraduate, 25 masters, and 12 doctoral students. The department participates in many interdisciplinary research centers and is lead in two - the Mack-Blackwell National Rural Transportation Center and the Computational Mechanics Laboratory. Last fiscal year, externally-funded research expenditures in the department exceeded \$1.6 million.

\section{Current BSCE Curriculum}

The department of civil engineering at [University A] offers the BSCE, which has been continuously accredited by ABET since 1936. A major curricular redesign was completed and implemented in 2004 which enabled the department to address perceived shortcomings in the undergraduate culminating design experience and to better position the department for subsequent ABET-related assessment. A revised set of program outcomes were developed and implemented Fall 2006.

Table 1 provides the program outcomes that were developed and implemented beginning Fall 2006. The program outcomes include the ABET Criterion $3(\mathrm{a}-\mathrm{k})$ outcomes plus additional outcomes unique to the department. It is noted that the program outcomes were somewhat 'informed' by the BOK1, but changes were not made specifically to address BOK outcomes.

The Fall 2009 curriculum is presented in Table 2, which follows the accustomed ABET/EAC self-study standard format. Highlights regarding the curriculum follow:

Core Curriculum: The university has a core curriculum requirement which includes 6 semester hours of english composition, 6 hours of humanities, 6 hours of social sciences, and 3 hours of U.S. History or political science.

Technical Electives: A total of 12 semester hours of "technical electives" are allowed in the curriculum. Only in rare cases would an elective course outside the Department of Civil Engineering be allowed for credit toward the BSCE. 
Freshman Engineering: The College of Engineering implemented a Freshman Engineering program in Fall 2007 to provide a common freshman experience for engineering majors. The primary goal of the freshman program is to improve $1^{\text {st }}$-year to $2^{\text {nd }}$-year retention across the College. As a result, there are no civil engineering courses offered to first-year students.

Culminating Design Experience. The technical component places a strong emphasis on engineering design. As shown in Table 2, twelve of the required civil engineering classes involve significant design content as do most of the engineering elective courses. The major design experience requirement is met through completion of two required design projects. Four major design project courses are offered each having its primary focus in one of the 4 technical areas emphasized by the program. The student must complete two of these.

Each design project course is tied to a course in the focus technical area that must be taken along with the design project. For example, a student who elects to take the transportation design project (CVEG 4831) must take CVEG 4433, Transportation Pavements and Materials, at the same time. While the design project is tied to the corequisite course, it is also independent in that students can take the corequisite without participating in the design project. The following is a list of the required corequisites.

DESIGN PROJECT COURSE

CVEG 4811 Environmental Design Project

CVEG 4821 Geotechnical Design Project

CVEG 4831 Structural Design Project

CVEG 4841 Transportation Design Project
REQUIRED COREQUISITE

CVEG 4243 Environmental Engineering Design

CVEG 4143 Foundation Engineering

CVEG 4323 Design of Structural Systems

CVEG 4443 Transportation Pavements \& Materials

Although the design projects have a primary focus in a selected technical area, they are not narrowly focused to that area. The projects are organized to resemble projects the students are likely to encounter after graduation. In this respect, the projects require knowledge and skills acquired from many courses that were taken earlier in the curriculum and they incorporate the need for the students to consult and comply with engineering standards and to address numerous realistic constraints.

\section{Evaluation of Current Curriculum vs. BOK2 Outcomes}

Current BSCE program outcomes for [University A] (Table 1) were 'mapped' against the BOK2 baccalaureate outcomes published by ASCE, and an initial assessment was conducted to identify likely action(s) needed to bring the [University A] program outcomes into better agreement or compliance with BOK2 outcomes. Table 3 presents a very brief summary of the effort. This type of exercise is limited by the nature of existing [University A] outcomes - which typically do not specify a "level of achievement" - versus the BOK2 approach of stating outcomes with definitive achievement levels.

While not included in this paper, all existing program outcomes are linked to at least two courses (more for many outcomes) within the curriculum. Program outcome assessment is accomplished through a variety of approaches. Many courses contain an embedded 'direct assessment' specific homework assignments, test questions, etc. - to demonstrate student achievement. Student performance in targeted subject areas on the Fundamentals of Engineering (FE) exam is compared to national norms (all students in civil engineering must attempt the FE exam prior to 
graduation). These types of assessments, while effective, lend themselves primarily to a 'yea/nea' approach, rather than specifying a particular level of achievement as exhibited in the BOK2 outcomes. It is noted that most of the likely action(s) listed in Table 3 (to better relate program outcomes to BOK2 outcomes) are related to increasing the degree of specificity or establishing a level of achievement for the outcome.

Figure 3 is a (conceptual) graphical comparison of the BSCE program outcomes with the BOK2 rubric. For reference, the 11 "challenging" outcomes identified by the Body of Knowledge Educational Fulfillment Committee ${ }^{5}$ are shaded red in the first column of the figure. Also represented in Figure 3, once again, is the recommended level of achievement expected to be fulfilled through the baccalaureate degree (B), the master's degree or equivalent post-

baccalaureate formal education (M/30), and pre-licensure experience $(E)$. The green shaded cells indicate the BOK2 outcomes that are fully fulfilled by the current BSCE curriculum; the yellow shaded cells indicate partial fulfillment of the outcome by the current curriculum. For the purpose of this comparison, 'partial fulfillment' indicates that some of the outcome is met by all students in the program. All BOK2 outcomes are addressed to some extent in the current BSCE program; however, a number of BOK2 outcomes are not currently fulfilled in the program at the specified level of achievement.

Figure 3 was developed primarily considering the specific learning outcomes for each course in the current program curriculum. Starting in 2008, the faculty developed a listing of specific learning outcomes for each course, informed somewhat by the principles of Bloom's Taxonomy. These outcomes suggest particular targeted levels of achievement for students in each course. At the end of each semester, students self-assess their success at achieving each outcome. Faculty use the students' self-assessment in conjunction with their own assessment of course outcomes to refine teaching/learning approaches and relative emphasis on topics. Work is underway, but not yet complete, to comprehensively 'map' individual course outcomes onto the overall program outcomes.

\section{Current Curriculum and the "Challenging" BOK2 Outcomes}

Considering the so-called "challenging" BOK2 outcomes as identified by the BOKEdFC 5 , the current curriculum at [University A] only partially addresses BOK2 outcomes 3, 4, 5, 10, 11, 12, $17,18,19,20$, and 24. A more detailed discussion of how the curriculum addresses (or fails to address) these "challenging" outcomes follows:

Outcome 3 - Humanities: The BOK2 envisions graduates with a bachelor's degree in civil engineering to "demonstrate the importance of the humanities in the professional practice of engineering." The university's core curriculum requires 9 hours of humanities, but without any tie to the student's major. The importance of the humanities to the practice of civil engineering is discussed in several courses - the primary course being CVEG 4852 Professional Practice Issues. The current program outcome requires the student only "understand" the importance of humanities in the context of civil engineering solutions; the BOK2 outcome, however, requires students to "demonstrate." The faculty has not yet developed a learning objective, nor an assessment tool, to gauge students' proficiency at "demonstrating" the importance of humanities in professional practice. 
Outcome 4 - Social Sciences: Similar to Outcome 3, the BOK2 aspires to have graduates "demonstrate the incorporation of social sciences knowledge into the professional practice of engineering." As part of the core curriculum, 9 hours of history and social sciences is required; in addition, students must complete two hours of engineering economics - in which principles of both micro and macroeconomics are incorporated. Similar to the humanities, the current program outcome only requires the student to "understand" the importance of the social sciences in the context of civil engineering solutions. The importance of social science to the practice of civil engineering is discussed in several courses, particularly when public works and policy are a focus as in CVEG 3413 Transportation Engineering, CVEG 4433 Transportation Pavements and Materials, CVEG 3213 Introduction to Environmental Engineering, and CVEG 4852 Professional Practice Issues. The faculty has not yet developed a specific learning objective, nor an assessment tool, to gauge students' proficiency at "demonstrating" the importance of social sciences in professional practice.

Outcome 5 - Material Science: The BOK2 envisions graduates to "use knowledge of materials science to solve problems appropriate to civil engineering." At [University A], this outcome is combined with BOK2 Outcome 6 - Mechanics. The outcome is satisfied largely through the required courses MEEG 3013 Mechanics of Materials, CVEG 2113 Structural Materials, and CVEG 4433 Transportation Pavements and Materials. The materials courses complement the mechanics of materials course and provide instruction on both materials science and mechanics of several traditional and new materials used in civil engineering. However, the CVEG materials courses place emphasis on engineering properties and tests rather than pure 'materials science'. For this reason, the projected level of achievement of the outcome falls short of the BOK2 target. The faculty has not developed a specific learning objective or assessment tool related to material science.

Outcome 10 - Sustainability: The BOK2 expects future graduates to "apply the principles of sustainability to the design of traditional and emergent engineering systems." The current curriculum places a heavy emphasis on design, and sustainability is integrated with "realistic constraints" in design courses. Sustainability concepts are covered well within the multiple required design courses and in CVEG 4852 Professional Practice Issues. The students have a good understanding of sustainability concepts; however, it has not been common practice to consider sustainability as a delineated, separate design criterion in student designs. The faculty has not developed specific learning objectives or assessment tools specifically targeted to sustainability.

Outcome 11 - Contemporary Issues \& History: The BOK2 expects students, "drawing upon a broad education, explain the impact of historical and contemporary issues on the identification, formulation, and solution of engineering problems and explain the impact of engineering solutions on the economy, environment, political landscape, and society." For the current program outcome, students are expected to "understand" the impact of issues on engineering problems and solutions - a level of achievement below that required by the BOK2. The program outcome is currently achieved within the context of several courses notably in CVEG 4852 Professional Practice Issues. In addition, historical impact and contemporary issues are addressed in the Freshman Engineering program. The students' understanding of potential impacts is somewhat demonstrated in design courses related to public works and infrastructure such as CVEG 4433 Transportation Pavements and Materials and CVEG 4243 Environmental Engineering Design. However, the faculty has not 
developed specific learning objectives or assessment tools specifically targeted to the demonstration of the impact of historical and contemporary issues on engineering solutions.

Outcome 12 - Risk \& Uncertainty: The BOK2 envisions graduates with a bachelor's degree in civil engineering to "apply the principles of probability and statistics to solve problems containing uncertainties." The program outcomes do not explicitly address the solution of problems containing uncertainties, but certainly address the application of principles of probability and statistics. The BSCE curriculum requires INEG 3313 Engineering Statistics, an applied engineering probability and statistics course that does include, to some degree, solving problems with uncertainty. Some specific design courses will feature, on a nonregular basis, probabilistic design concepts and problems. However, this is not a systematic requirement in the curriculum.

Outcome 17 - Public Policy: Under the BOK2, future graduates will be expected to "discuss and explain key concepts and processes involved in public policy." The program outcome combines this outcome with BOK2 Outcome 18 - Business \& Public Administration. While public policy issues are integrated throughout the curriculum - most notably in courses related to public works and infrastructure - specific public policy discussions are conducted in CVEG 4852 Professional Practice Issues. It is not clear in current courses whether all students rise to the level of achievement required by the BOK2. Learning objectives and associated assessment tools need to be reexamined to ensure compliance at the specified level of achievement.

Outcome 18 - Business \& Public Administration: Following the BOK2, graduates with a CE degree will be expected to "explain key concepts and processes used in business and public administration." As described in Outcome 17, this BOK2 outcome is combined with BOK2 outcomes 17 within a single program outcome. The difference is that the BOK2 expects students to "explain key concepts and processes" where the program expects students to "explain ... concepts." Business and public administration is a focal point of both CVEG 4852 Professional Practice Issues and CVEG 4513 Construction Management. Specific learning objectives and associated assessment tools need to be developed to ensure compliance with BOK2 outcomes at the specified level of achievement.

Outcome 19 - Globalization: This new outcome to the BOK2 expects students to "organize, formulate, and solve engineering problems within a global context." The current program outcome includes globalization in a list of design contexts for which the student demonstrates "understanding". The concept of globalization is integrated into various design courses and discussed in CVEG 4852 Professional Practice Issues and CVEG 4513 Construction Management. The faculty has not developed specific learning objectives or assessment tools specifically targeted to globalization.

Outcome 20 - Leadership: The BOK2 envisions civil engineering graduates of the future to "apply leadership principles to direct the efforts of a small, homogenous group." The program outcome requires students to "explain the basic concepts in...leadership", a level of achievement below that required by the BOK2. Leadership principles are introduced in the Freshman Engineering program, and discussed thoroughly in CVEG 4852 Professional Practice Issues. In addition, the curriculum places heavy emphasis on teamwork, both the in numerous laboratory courses and in design courses (virtually all laboratory and design work at the late-Junior and Senior levels is done in teams). Leadership and teamwork skills are 
reinforced throughout the curriculum. However, the faculty has not developed specific learning objectives or assessment tools specifically targeted to the demonstration of leadership.

Outcome 24 - Professional \& Ethics: The BOK2 outcome requiring students to "analyze a situation involving multiple conflicting professional and ethical interests to determine an appropriate course of action" is not new to civil engineering curricula. The current program outcome expects graduates to "understand" ethical and professional issues, which does not rise to the same level of achievement as the BOK2 outcome. Professionalism and ethics are introduced in the Freshman Engineering program, reinforced in multiple courses throughout the curriculum, and made a primary focus in CVEG 4852 Professional Practice Issues. The program outcome adds "the importance of professional licensure" in addition to professional and ethical issues. The program outcome is relatively easily adjusted to comply with the level of achievement required by the BOK2 by the addition of learning objectives (and appropriate assessment tools) related to the students' demonstration of selecting a course of action in the face of multiple conflicting interests.

\section{Aligning Program Curriculum and the BOK2 Outcomes}

A question facing any program considering 'compliance' with BOK2 outcomes is "... at what cost?" Comprehensive curricular redesign, unfortunately, cannot be accomplished in a vacuum there exist real constraints imposed by the institution, the state, ABET EAC criteria, and in many cases the values expressed by the program's external constituencies. The civil engineering program at [University A] is fortunate, from the perspective that a major curricular redesign does not appear warranted.

Figure 3 indicates that each BOK2 outcome is addressed by the existing curriculum. The primary shortcomings of the existing curriculum, as indicated in Table 3 and discussed in the previous section, include the specificity of program outcomes, and the level of achievement envisioned (and described) for topical areas. This is not to suggest the effort to refashion program outcomes to better comply with the BOK2 is trivial. Indeed, this effort will require rewriting all existing program outcomes to capture both the outcome content and level of achievement of the BOK2 - while maintaining compliance with ABET EAC general-level and program criteria. One example of such an approach is provided by Fridley ${ }^{7}$.

An example illustrates the approach underway at [University A]. At the baccalaureate (B) level, BOK2 outcome 16, Communication, requires students to:

"Organize and deliver effective verbal, written, virtual, and graphical communications"

The current civil engineering program criteria at [University A] - outcome $(\mathrm{h})$ - requires students to:

(have) "an ability to communicate effectively"

In this case, the program criteria at [University A] will be changed to a restatement of the BOK2 outcome statement. 
It must be noted that a key component supporting this change are individual course learning outcomes that 'contribute' to this program outcome. For example, one course learning outcome for CVEG 4433, Transportation Pavements and Materials, is:

"Prepare a professional design report which details a hot-mix asphalt mixture design; prepare a professional design report which details a structural pavement design."

There are additional, similar course learning outcomes throughout the existing curriculum. These not only provide support for the program outcome, but also provide direct opportunities for assessment - demonstrating achievement of the outcome at the specified level.

Unfortunately, all changes are not as straightforward as the example for communications. Table 3 indicates "new" program outcomes will be required. Table 4 shows both the existing program outcomes for [University A] and proposed program outcomes, which bring the curriculum into greater compliance with current BOK2 outcomes. It is noted that the number of program outcomes grows from 13 (currently) to 15 (proposed). However, it is fully anticipated that these changes may be made within the context of the existing curriculum. Based on the analysis of the existing curriculum as detailed in this paper, it is not anticipated that any addition or deletion of courses will be necessary to bring the curriculum into reasonable compliance with the BOK2.

\section{Conclusion}

This paper provides an analysis of the undergraduate civil engineering curriculum at [University A], a small-to-medium sized program at a land-grant research university, with respect to the proposed educational outcomes of the BOK2. A number of 'challenging' outcomes are specifically identified and discussed.

The undergraduate civil engineering curriculum of [University A] includes 132 semester credit hours. The program is currently governed by 13 outcomes, which comply with current baccalaureate-level general and program criteria as defined by the EAC of ABET. The current curriculum addresses, in some fashion, all 24 BOK2 outcomes. The program fully addresses, to the recommended level of achievement, 6 of the 24 BOK2 outcomes; the remaining 18 BOK2 outcomes are not addressed to the specified level of achievement for the baccalaureate level.

Three interrelated actions are identified as necessary for bringing the undergraduate curriculum to substantial compliance with the BOK2. The first is a review and refinement of existing program outcomes. Current outcomes are stated in a manner similar to that used in current ABET EAC criteria, and do not necessarily suggest a level-of-achievement similar to that specified in the BOK2. Program outcomes will be restated to better identify the content and level of achievement expected of students completing the program. In addition, at least two new and/or additional program outcomes may be necessary to fully comply with the requirements of the BOK2. It is important to note that these new and/or restated program outcomes will also reflect current baccalaureate-level general and program criteria as defined by the EAC of ABET. 
The second associated action involves a comprehensive curricular content review, to ensure existing courses provide both the content and the level of achievement envisioned by the BOK2. Individual course learning outcomes will be refined to more directly align with the BOK2. A course 'map', which identifies specific courses which contribute to each of the BOK2 outcomes, has been drafted. This map will be further developed at an 'outcome' level, e.g. course-specific outcomes will be mapped for their contribution to the program/BOK2 outcomes.

The third action relates to the refinement of existing, and development of new, assessment tools to demonstrate student achievement relative to program/BOK2 outcomes. As noted previously, current assessment tools include some 'direct assessment' (or 'embedded indicators', as once termed) items, results from topical areas on the Fundamentals of Engineering (FE) examination, and others. Additional tools will be required; it is noted that the number of program outcomes will likely increase by at least five.

The question of the 'cost' of moving the undergraduate civil engineering curriculum to fuller compliance with the BOK2 is considered. At [University A] such an undertaking will require substantial effort 'up front' regarding a comprehensive review/refinement/development of program outcomes, course outcomes, and assessment tools. Due to the anticipated increase in program outcomes, there will be an associated increase in 'maintenance cost' of assessment data collection and analysis. Some course content may be restructured or refined; however, significant course/program restructuring - including adding, deleting, or changing courses - is not anticipated.

\section{Bibliography}

1. ASCE Body of Knowledge Committee of CAP^3. 2004. Civil Engineering Body of Knowledge for the $2 I^{\text {st }}$ Century: Preparing the Civil Engineer for the Future, Reston, VA, January. (http://www.asce.org/raisethebar).

2. ASCE Body of Knowledge II Committee of $\mathrm{CAP}^{\wedge} 3$. 2008. Civil Engineering Body of Knowledge for the $21^{\text {st }}$ Century: Preparing the Civil Engineer for the Future, Second Edition, Reston, VA, January. (http://www.asce.org/raisethebar).

3. Ressler, S., "Influence of the New Civil Engineering Body of Knowledge on Accreditation Criteria", Proceedings of the 2008 ASEE Annual Conference, June 2008, Pittsburgh, PA.

4. ASCE Levels of Achievement Subcommittee of CAP^3. 2005. Levels of Achievement Applicable to the Body of Knowledge Required for Entry Into the Practice of Civil Engineering at the Professional Level, Reston, VA, September. (http://www.asce.org/raisethebar)

5. Bloom. B. S., Englehart, M. D., Furst. E. J., Hill, W. H., and Krathwohl, D. 1956. Taxonomy of Educational Objectives, the Classification of Educational Goals, Handbook I: Cognitive Domain. David McKay, New York, NY.

6. Fridley, K.J., et al., 2009. "Educating the Future Civil Engineering for the New Civil Engineering Body of Knowledge," Proceedings of the 2009 ASEE Annual Conference, June 2009, Austin, TX.

7. Fridley, K.J., "How the Civil Engineering BOK2 Is Being Implemented at [The University of Alabama]", presented to the ASCE Body of Knowledge Educational Fulfillment Committee (BOKEdFC), August 2009. 


\begin{tabular}{|c|c|c|c|c|c|c|c|}
\hline \multirow[b]{2}{*}{ OUTCOME \# } & \multirow[b]{2}{*}{ OUTCOME TITLE } & \multicolumn{6}{|c|}{ BLOOM'S LEVEL OF ACHIEVEMENT (LOA) } \\
\hline & & 1 & 2 & 3 & 4 & 5 & 6 \\
\hline 1 & Mathematics & B & B & B & & & \\
\hline 2 & Natural Sciences & $\mathbf{B}$ & B & B & & & \\
\hline 3 & Humanities & $\mathbf{B}$ & B & B & & & \\
\hline 4 & Social Sciences & B & B & B & & & \\
\hline 5 & Material Science & B & B & B & & & \\
\hline 6 & Mechanics & B & B & B & B & & \\
\hline 7 & Experiments & $\mathbf{B}$ & B & B & B & $\mathrm{M} / 30$ & \\
\hline 8 & Problem Recognition \& Solving & B & B & B & $\mathrm{M} / 30$ & & \\
\hline 9 & Design & B & B & B & B & B & $\mathbf{E}$ \\
\hline 10 & Sustainability & B & B & B & E & & \\
\hline 11 & Contemporary Issues \& History & $\mathbf{B}$ & B & B & $\mathbf{E}$ & & \\
\hline 12 & Risk \& Uncertainty & B & B & B & E & & \\
\hline 13 & Project Management & B & B & B & E & & \\
\hline 14 & Breadth in CE & B & B & B & B & & \\
\hline 15 & Tech Specialization & B & $M / 30$ & $\mathrm{M} / 30$ & $\mathrm{M} / 30$ & $\mathrm{M} / 30$ & $\mathbf{E}$ \\
\hline 16 & Communication & B & B & B & B & $\mathbf{E}$ & \\
\hline 17 & Public Policy & B & B & $\mathbf{E}$ & & & \\
\hline 18 & Business \& Public Admin & B & B & $\mathbf{E}$ & & & \\
\hline 19 & Globalization & B & B & B & E & & \\
\hline 20 & Leadership & B & B & B & $\mathrm{E}$ & & \\
\hline 21 & Teamwork & B & B & B & $E$ & & \\
\hline 22 & Attitudes & B & B & $\mathbf{E}$ & & & \\
\hline 23 & Lifelong Learning & B & B & B & E & $\mathbf{E}$ & \\
\hline 24 & Professional \& Ethics & B & B & B & B & $\mathbf{E}$ & $\mathbf{E}$ \\
\hline
\end{tabular}

Figure 1: Graphical Representation of the BOK2 Outcome Rubric 


\begin{tabular}{|c|c|c|c|c|c|c|c|}
\hline \multirow[b]{2}{*}{ OUTCOME \# } & \multirow[b]{2}{*}{ OUTCOME TITLE } & \multicolumn{6}{|c|}{ BLOOM'S LEVEL OF ACHIEVEMENT (LOA) } \\
\hline & & 1 & 2 & 3 & 4 & 5 & 6 \\
\hline 1 & Mathematics & 10 & 10 & 9 & 2 & 0 & 0 \\
\hline 2 & Natural Sciences & 10 & 10 & 9 & 2 & 0 & 0 \\
\hline 3 & Humanities & 6 & 5 & 3 & 2 & 0 & 0 \\
\hline 4 & Social Sciences & 7 & 4 & 2 & 1 & 0 & 0 \\
\hline 5 & Material Science & 9 & 7 & 5 & 2 & 0 & 0 \\
\hline 6 & Mechanics & 10 & 9 & 9 & 7 & 0 & 0 \\
\hline 7 & Experiments & 9 & 9 & 9 & 8 & 2 & 0 \\
\hline 8 & Problem Recognition \& Solving & 10 & 9 & 9 & 2 & 1 & 0 \\
\hline 9 & Design & 9 & 10 & 9 & 8 & 7 & 0 \\
\hline 10 & Sustainability & 6 & 3 & 2 & 2 & 0 & 0 \\
\hline 11 & Contemporary Issues \& History & 7 & 3 & 2 & 1 & 0 & 0 \\
\hline 12 & Risk \& Uncertainty & 7 & 3 & 2 & 1 & 0 & 0 \\
\hline 13 & Project Management & 9 & 9 & 6 & 0 & 0 & 0 \\
\hline 14 & Breadth in CE & 10 & 10 & 9 & 9 & 0 & 0 \\
\hline 15 & Tech Specialization & 9 & 7 & 5 & 3 & 0 & 0 \\
\hline 16 & Communication & 10 & 10 & 8 & 8 & 2 & 0 \\
\hline 17 & Public Policy & 5 & 4 & 0 & 0 & 0 & 0 \\
\hline 18 & Business \& Public Admin & 7 & 4 & 0 & 0 & 0 & 0 \\
\hline 19 & Globalization & 5 & 3 & 1 & 0 & 0 & 0 \\
\hline 20 & Leadership & 9 & 7 & 4 & 0 & 0 & 0 \\
\hline 21 & Teamwork & 9 & 8 & 7 & 2 & 0 & 1 \\
\hline 22 & Attitudes & 7 & 7 & 0 & 0 & 0 & 0 \\
\hline 23 & Lifelong Learning & 10 & 10 & 9 & 0 & 0 & 0 \\
\hline 24 & Professional \& Ethics & 10 & 10 & 7 & 5 & 0 & 0 \\
\hline
\end{tabular}

Figure 2: Number of Programs (out of 10) Reporting All of the BOK2 Outcomes at Each LOA are Fulfilled by All of Their Baccalaureate Graduates. ${ }^{5}$ 
Table 1: [University A's] BSCE Program Outcomes

\begin{tabular}{|c|c|}
\hline \multicolumn{2}{|c|}{ Students graduating with a Bachelor of Science in Civil Engineering from the [University A] have: } \\
\hline Outcome a & $\begin{array}{l}\text { an ability to apply knowledge of mathematics and science in the solution of civil } \\
\text { engineering problems }\end{array}$ \\
\hline Outcome b & $\begin{array}{l}\text { an ability to design and conduct civil engineering experiments and analyze and } \\
\text { interpret the resulting data }\end{array}$ \\
\hline Outcome c & $\begin{array}{l}\text { an ability to design a system, component, or process to meet desired needs within the } \\
\text { context of at least two civil engineering areas and considering realistic constraints } \\
\text { such as economic, environmental, social, political, ethical, health and safety, } \\
\text { manufacturability, and sustainability }\end{array}$ \\
\hline Outcome d & an ability to function on multidisciplinary teams \\
\hline Outcome e & $\begin{array}{l}\text { an ability to apply knowledge of the environmental, geotechnical, structural, and } \\
\text { transportation areas to the solution of engineering problems }\end{array}$ \\
\hline Outcome $\mathrm{f}$ & an ability to identify, formulate, and solve engineering problems \\
\hline Outcome g & $\begin{array}{l}\text { an understanding of professional and ethical responsibility including the importance } \\
\text { of professional licensure }\end{array}$ \\
\hline Outcome h & an ability to communicate effectively \\
\hline Outcome i & $\begin{array}{l}\text { the broad education necessary to understand the impact of engineering solutions in a } \\
\text { global, economic, environmental, and societal context }\end{array}$ \\
\hline Outcome j & a recognition of the need for, and an ability to engage in life-long learning \\
\hline Outcome k & a knowledge of contemporary issues \\
\hline Outcome 1 & $\begin{array}{l}\text { an ability to use the techniques, skills, and modern engineering tools necessary for } \\
\text { engineering practice }\end{array}$ \\
\hline Outcome m & $\begin{array}{l}\text { an ability to explain the basic concepts in management, business, public policy, and } \\
\text { leadership. }\end{array}$ \\
\hline
\end{tabular}


Table 2: [University A's] Bachelor of Science in Civil Engineering Curriculum.

\begin{tabular}{|c|c|c|c|c|c|}
\hline \multirow[b]{2}{*}{$\begin{array}{c}\text { Year; } \\
\text { Semester or } \\
\text { Quarter }\end{array}$} & \multirow[b]{2}{*}{$\begin{array}{l}\text { Course } \\
\text { ent, Number, Title) }\end{array}$} & \multicolumn{4}{|c|}{ Category (Credit Hours) } \\
\hline & & $\begin{array}{c}\text { Math \& } \\
\text { Basic } \\
\text { Sciences }\end{array}$ & \begin{tabular}{|} 
Engineering \\
Topics \\
Check if Contains \\
$\frac{\text { Significant Design }}{(X)}$
\end{tabular} & $\begin{array}{c}\text { General } \\
\text { Education }\end{array}$ & Other \\
\hline \multirow[t]{6}{*}{ Year 1, Fall } & ENGL 1013 Composition I & & & & 3 \\
\hline & \begin{tabular}{|l} 
MATH 2554 Calculus I \\
\end{tabular} & 4 & & & \\
\hline & CHEM 1103 University Chemistry I & 3 & & & \\
\hline & PHYS 2054 University Physics I & 4 & & & \\
\hline & PHYS 2050L Univ. Physics I Lab & & & & \\
\hline & GNEG 1111 Intro to Engineering I & & 1 & & \\
\hline \multirow[t]{6}{*}{ Year 1, Spring } & ENGL 1023 Tech Composition II & & & & 3 \\
\hline & Freshman Science Elective & 3 & & & \\
\hline & Freshman Science Elective Lab & 1 & & & \\
\hline & MATH 2564 Calculus II & 4 & & & \\
\hline & Humanity/social science elective & & & 3 & \\
\hline & GNEG 1121 Intro to Engineering II & & 1 & & \\
\hline \multirow[t]{6}{*}{ Year 2, Fall } & MATH 2574 Calculus III & 4 & & & \\
\hline & MEEG 2003 Statics & & 3 & & \\
\hline & Humanity/social science elective & & & 3 & \\
\hline & CVEG 2053 Surveying Systems & & 3 & & \\
\hline & CVEG 2051L Survey Systems Lab & & 1 & & \\
\hline & GNEG 1122 Introduction CAD & & 2 & & \\
\hline \multirow[t]{6}{*}{ Year 2, Spring } & CVEG 2113 Structural Materials & & 3 & & \\
\hline & INEG 3313 Engineering Statistics & 3 & & & \\
\hline & MATH 3404 Differential Equations & 4 & & & \\
\hline & MEEG 3013 Mechanics of Materials & & 3 & & \\
\hline & GEOL 3002 Geology for Engineers & 2 & & & \\
\hline & Humanity/social science elective & & & 3 & \\
\hline \multirow[t]{5}{*}{ Year 3, Fall } & CVEG 3304 Structural Analysis & & 4 & & \\
\hline & CVEG 3133 Soil Mechanics & & 3 & & \\
\hline & CVEG 3213 Hydraulics & & $3(X)$ & & \\
\hline & CVEG 3413 Transportation Engr & & $3(X)$ & & \\
\hline & \begin{tabular}{|l} 
Science Elective \\
\end{tabular} & 4 & & & \\
\hline \multirow[t]{6}{*}{ Year 3, Spring } & CVEG 3022 Public Works Econ & & 2 & & \\
\hline & CVEG 3223 Hydrology & & $3(\mathrm{X})$ & & \\
\hline & CVEG 3243 Environmental Engr & & $3(\mathrm{X})$ & & \\
\hline & \begin{tabular}{|l} 
CVEG 4313 Structural Steel Design I \\
\end{tabular} & & $3(\mathrm{X})$ & & \\
\hline & Humanity/social science elective & & & 3 & \\
\hline & Engineering elective & & $3\left(^{*}\right)$ & & \\
\hline \multirow[t]{7}{*}{ Year 4, Fall } & CVEG 4143 Foundation Engineering & & $3(X)$ & & \\
\hline & CVEG 4303 Reinf Concrete Design I & & $3(X)$ & & \\
\hline & CVEG 4433 Trans Pavements \& Mtl & & $3(X)$ & & \\
\hline & CVEG 4852 Prof Practice Issues & & $2(X)$ & & \\
\hline & \begin{tabular}{|l} 
Engineering elective \\
\end{tabular} & & $3\left(^{*}\right)$ & & \\
\hline & Humanity/social science elective & & & 3 & \\
\hline & \begin{tabular}{|l} 
Civil engineering design elective \\
\end{tabular} & & $1(\mathrm{X})$ & & \\
\hline \multirow[t]{5}{*}{ Year 4, Spring } & CVEG 4243 Environ Engr Design & & $3(X)$ & & \\
\hline & CVEG 4513 Construction Mgmt & & 3 & & \\
\hline & Engineering electives & & $6\left(^{*}\right)$ & & \\
\hline & Civil engineering design elective & & $1(\mathrm{X})$ & & \\
\hline & Humanity/social science elective & & & 3 & \\
\hline \multicolumn{2}{|c|}{ TOTALS-ABET BASIC-LEVEL REQUIREMENTS } & 36 & 72 & 18 & 6 \\
\hline OVERALL TOT & TAL FOR DEGREE & & & & \\
\hline \multicolumn{2}{|c|}{ PERCENT OF TOTAL } & $27.2 \%$ & $52.9 \%$ & $13.6 \%$ & $4.5 \%$ \\
\hline \multirow{2}{*}{$\begin{array}{r}\text { Totals must } \\
\text { satisfy one set }\end{array}$} & Minimum semester credit hours & $32 \mathrm{hrs}$ & $48 \mathrm{hrs}$ & & \\
\hline & Minimum percentage & $25 \%$ & $37.5 \%$ & & \\
\hline
\end{tabular}


Table 3. Mapping of BOK2 Outcomes with [University A's] Fall 2009 Program Outcomes (Table 2).

\begin{tabular}{|c|c|c|}
\hline $\begin{array}{c}\text { BOK2 Outcome Title } \\
\text { ('B”' Level of Achievement) }\end{array}$ & $\begin{array}{l}\text { BSCE Program } \\
\text { Outcomes }\end{array}$ & Identified Actions Needed \\
\hline 1. Mathematics (3) & \multirow{2}{*}{ (a) } & \\
\hline 2. Natural Sciences (3) & & \\
\hline 3. Humanities (3) & \multirow{2}{*}{ (i) } & \multirow{2}{*}{ New outcome to increase specificity; add LOA } \\
\hline 4. Social Sciences (3) & & \\
\hline 5. Material Science (3) & \multirow{2}{*}{ (f) } & \multirow{2}{*}{ New outcome to increase specificity; add LOA } \\
\hline 6. Mechanics (3) & & \\
\hline 7. Experiments (4) & (b) & Increase specificity \\
\hline $\begin{array}{l}\text { 8. Problem Recognition and } \\
\text { Solving (3) }\end{array}$ & (f) \& (l) & Combine program outcomes \\
\hline 9. Design (5) & \multirow{2}{*}{ (c) } & \\
\hline 10. Sustainability (3) & & New outcome to increase specificity; add LOA \\
\hline $\begin{array}{l}\text { 11. Contemporary Issues \& } \\
\text { History (3) }\end{array}$ & (i) & Increase LOA \\
\hline 12. Risk \& Uncertainty (3) & (f) & New outcome to increase specificity; add LOA \\
\hline 13. Project Management (3) & $(\mathrm{m})$ & Subdivide program outcome; increase LOA \\
\hline 14. Breadth in CE (4) & (e) & \\
\hline 15. Tech Specialization (1) & & New outcome; add LOA \\
\hline 16. Communication (4) & (h) & Restate program outcome \\
\hline 17. Public Policy (2) & \multirow[b]{2}{*}{$(\mathrm{m})$} & Subdivide program outcome \\
\hline $\begin{array}{l}\text { 18. Business \& Public } \\
\text { Administration (2) }\end{array}$ & & Subdivide program outcome \\
\hline 19. Globalization (3) & (i) & \\
\hline 20. Leadership (3) & (m) & Subdivide program outcome; increase LOA \\
\hline 21. Teamwork (3) & (d) & \\
\hline 22. Attitudes (3) & $(\mathrm{g})$ & Restate program outcome \\
\hline 23. Lifelong Learning (3) & (j) & Restate program outcome; add LOA \\
\hline 24. Professional \& Ethics (4) & (g) & Increase LOA \\
\hline
\end{tabular}




\begin{tabular}{|c|c|c|c|c|c|c|c|c|}
\hline \multirow{2}{*}{$\begin{array}{c}\text { BOK2 } \\
\text { Outcome }\end{array}$} & \multirow{2}{*}{$\begin{array}{c}\text { BOK2 } \\
\text { Outcome Name }\end{array}$} & \multirow{2}{*}{$\begin{array}{c}\text { BSCE } \\
\text { Outcome }\end{array}$} & \multicolumn{6}{|c|}{ BLOOM'S LEVEL OF ACHIEVEMENT (LOA) } \\
\hline & & & 1 & 2 & 3 & 4 & 5 & 6 \\
\hline 1 & Mathematics & $\mathrm{a}$ & $\mathrm{B}$ & $\mathrm{B}$ & $\mathrm{B}$ & & & \\
\hline 2 & Natural Sciences & a & $\mathrm{B}$ & $\mathrm{B}$ & $\mathrm{B}$ & & & \\
\hline 3 & Humanities & $\mathrm{i}$ & $\mathrm{B}$ & B & $\mathrm{B}$ & & & \\
\hline 4 & Social Sciences & $\mathrm{i}$ & $\mathrm{B}$ & B & B & & & \\
\hline 5 & Material Science & $\mathrm{f}$ & $\mathrm{B}$ & $\mathrm{B}$ & $\mathrm{B}$ & & & \\
\hline 6 & Mechanics & $\mathrm{b}$ & $\mathrm{B}$ & $\mathrm{B}$ & $\mathrm{B}$ & $\mathrm{B}$ & & \\
\hline 7 & Experiments & $\mathrm{f}$ & $\mathrm{B}$ & $\mathrm{B}$ & $\mathrm{B}$ & $\mathrm{B}$ & $\mathrm{M} / 30$ & \\
\hline 8 & Problem Recognition \& Solving & 1 & $\mathrm{~B}$ & $\mathrm{~B}$ & $\mathrm{~B}$ & $\mathrm{M} / 30$ & & \\
\hline 9 & Design & $\mathrm{c}$ & $\mathrm{B}$ & B & $\mathrm{B}$ & $\mathrm{B}$ & B & $\mathrm{E}$ \\
\hline 10 & Sustainability & $\mathrm{c}$ & $\mathrm{B}$ & $\mathrm{B}$ & $\mathrm{B}$ & $\mathrm{E}$ & & \\
\hline 11 & Contemporary Issues \& History & $\mathrm{i}$ & $\mathrm{B}$ & $\mathrm{B}$ & $\mathrm{B}$ & $\mathrm{E}$ & & \\
\hline 12 & Risk \& Uncertainty & $\mathrm{f}$ & $\mathrm{B}$ & $\mathrm{B}$ & B & $\mathrm{E}$ & & \\
\hline 13 & Project Management & $\mathrm{m}$ & $\mathrm{B}$ & B & B & $\mathrm{E}$ & & \\
\hline 14 & Breadth in CE & e & $\mathrm{B}$ & B & B & B & & \\
\hline 15 & Tech Specialization & -- & $\mathrm{B}$ & $\mathrm{M} / 30$ & $\mathrm{M} / 30$ & $\mathrm{M} / 30$ & $\mathrm{M} / 30$ & $\mathrm{E}$ \\
\hline 16 & Communication & $\mathrm{h}$ & $\mathrm{B}$ & $\mathrm{B}$ & $\mathrm{B}$ & $\mathrm{B}$ & E & \\
\hline 17 & Public Policy & $\mathrm{m}$ & B & $\mathrm{B}$ & $\mathrm{E}$ & & & \\
\hline 18 & Business \& Public Admin & $\mathrm{m}$ & $\mathrm{B}$ & B & E & & & \\
\hline 19 & Globalization & $\mathrm{i}$ & B & $\mathrm{B}$ & $\mathrm{B}$ & $\mathrm{E}$ & & \\
\hline 20 & Leadership & $\mathrm{m}$ & $\mathrm{B}$ & $\mathrm{B}$ & $\mathrm{B}$ & $\mathrm{E}$ & & \\
\hline 21 & Teamwork & d & $\mathrm{B}$ & B & $\mathrm{B}$ & $\mathrm{E}$ & & \\
\hline 22 & Attitudes & $\mathrm{g}$ & $\mathrm{B}$ & $\mathrm{B}$ & $\mathrm{E}$ & & & \\
\hline 23 & Lifelong Learning & $\mathrm{j}$ & $\mathrm{B}$ & B & $\mathrm{B}$ & $\mathrm{E}$ & E & \\
\hline 24 & Professional \& Ethics & $\mathrm{g}$ & $\mathrm{B}$ & B & B & B & $\mathrm{E}$ & $\mathrm{E}$ \\
\hline
\end{tabular}

Figure 3: Graphical Comparison of [University A's] BSCE Program Level of Achievement to BOK2 Outcomes. 
Table 4. Existing and Proposed Program Outcomes for [University A's].

\section{Existing Program Outcomes \\ (a) Graduates have an ability to apply knowledge of mathematics and science in the solution of civil engineering problems.}

(b) Graduates have an ability to design and conduct experiments and anlayze and interpret the resulting data.

(c) Graduates have an ability to design a system, component, or process to meet desired needs within the context of at least two civil engineering areas and considering realistic constrains such as economic, environmental, social, political, ethical, health and safety, manufacturability, and sustainability.

(d) Graduates have an ability to function on multidisiciplinary teams.

(e) Graduates have an ability to apply knowledge of the environmental, geotechnical, structural, and transportation areas to the solution of engineering problems.

(f) Graduates have an ability to identify, formulate, and solve engineering problems.

(1) Graduates have an ability to use the techniques, skills, and modern engineering tools necessary for engineering practice.

(g) Graduates have an understanding of professional and ethical responsibillity including the importance of professional licensure.

(h) Graduates have an ability to communicate effectively.

(i) Graduates have the broad education necessary to understand the impact of engineering solutions in a global, economic, environmental, and social context.

(j) Graduates have a recognition of the need for, and an ability to engage in life long learning.

(k) Graduates have a knowledge of contemporary issues

(m) Graduates have an ability to explain the basic concepts in management, business, public policy, and leadership.

\section{Proposed Program Outcomes} "Graduates Can..."

(UA1) Solve problems in mathematics through differential equations, probability and statistics, calculus-based physics, general chemistry, and one additional area of science.

(UA4) Select and conduct relevant experiments in multiple areas of civil engineering, and analyze and evaluate the resulting data.

(UA 6) Design a system, component, or process to meet desired needs within at least two program-relevant civil engineering areas, considering the principles of sustainability and including realistic constraints such as economic, environmental, social, political, ethical, health and safety, and constructability.

(UA12) Apply leadership principles to direct the efforts of a small group to solve a relatively constrained problem; and function effectively as a member of a multidisciplinary team to solve open-ended engineering problems.

(UA5) Apply relevant knowledge, techniques, skills, and modern engineering tools to identify, formulate, and solve engineering problems, including problems in at least four technical areas appropriate to civil engineering, and including problems containing uncertainty.

(UA 13) Explain the concept of 'professionalism'; discuss the importance of professional ethics and the importance of professional licensure.

(UA15) Analyze a situation involving multiple conflicting professional, legal, and ethical interests to determine an appropriate course of action.

(UA10) Organize and deliver effective verbal, written, virtual, and graphical communications.

(UA2) Explain the importance of humanities, history, and social behavior in the professional practice of civil engineering.

(UA14) Demonstrate the ability to learn through independent study, without the aid of formal instruction.

(UA7) Explain the impact of historical and contemporary issues on the identification, formulation, and solution of engineering problems and identify possible impacts of engineering solutions on the economy, environment, political landscape, and society.

(UA11) Explain key concepts and processes used in business, public administration, and public policy.

(UA3) Analyze and solve problems in materials science, mechanics of solids, and mechanics of fluids.

(UA8) Develop solutions to well-defined project management problems within civil engineering.

(UA9) Explain key aspects of at least one traditional or emerging program-relevant area of advanced specialization. 